\title{
Sale of Raw Milk in Northern Italy: Food Safety Implications and Comparison of Different Analytical Methodologies for Detection of Foodborne Pathogens
}

\author{
Federica Giacometti, Andrea Serraino,, Guido Finazzi, ${ }^{2}$ Paolo Daminelli, ${ }^{2}$ Marina N. Losio, \\ Norma Arrigoni, ${ }^{2}$ Silvia Piva, Daniela Florio, Raffaela Riu, and Renato G. Zanoni ${ }^{1}$
}

\begin{abstract}
The safety of raw milk sold in Northern Italy was investigated in relation to hygiene quality parameters and presence of Salmonella spp., Listeria monocytogenes, thermotolerant Campylobacter, and Verocytotoxin producing Escherichia coli O157:H7. The performance of different analytical methods used-official culture method (ISO), modified Bacteriological Analytical Manual cultural method (mBAM), and polymerase chain reaction (PCR)was evaluated. The presence of Mycobacterium avium subsp. paratuberculosis (Map) was investigated only by PCR. All samples met regulations for alkaline phosphatase and inhibitory substance, while $18 \%$ and $44.8 \%$ of samples collected from vending machines had, respectively, somatic cell count (SCC) $>300,000 / \mathrm{mL}$ and total bacterial count $(\mathrm{TBC})>50,000 \mathrm{CFU} / \mathrm{mL}$. The correlation between hygienic quality parameters in samples collected from bulk tank and vending machines showed a significant increase of TBC in vending machines meaning that raw milk was mishandled during distribution and sale. All pathogens investigated were detected in raw milk sold at vending machines; a total of five samples $(5 \%)$ had at least one pathogen, of which two were detected by PCR and three by mBAM. None of the samples was positive by cultural ISO methods. Even if the comparison of analytical methods showed that none performs significantly better than the others, testing a higher volume of milk ( 25 versus $210 \mathrm{~mL}$ ) affects significantly the detection rate of pathogens. Three samples $(3 \%)$ were positive for Map, suggesting that raw milk is a significant source of Map exposure for consumers. The observed TBC increase and the detection of several pathogenic bacteria pose questions on the safety of raw milk; the use of ISO seems inefficient in detecting a low contamination level of pathogens in milk and consequently not appropriate as official method for testing. In order to ensure consumer's safety, a new approach for the raw milk chain is required.
\end{abstract}

\section{Introduction}

$\mathbf{T}$ HE SALE OF RAW MILK for human consumption by selfservice automatic vending machines has been allowed in Italy since 2004. The presence of pathogenic bacteria in raw milk has been well documented both in Europe and in the United States, but the isolation rate reported has varied considerably (Oliver et al., 2005, 2009). In Italy, surveys on foodborne pathogens in raw milk were connected with official controls at vending machines. The Italian Ministry of Health reported a national prevalence of $3.85 \%$ for Salmonella spp., $14.42 \%$ for Listeria monocytogenes, $12.5 \%$ for thermotolerant Campylobacter, and $2.88 \%$ for Verocytotoxin producing Escherichia coli (VTEC) O157:H7 (http://www.salute.gov.it/ relazioneAnnuale2010/paginaInternaSottomenuRelazione
Annuale2010.jsp? $\mathrm{id}=410 \&$ lingua $=$ italiano \&menu $=$ cap2 \& sottomenu $=5$ ); unfortunately, official tests for microbiological criteria for direct sale of raw milk depend on regional rules that differ both for limits and analytical methods (mainly ISO cultural method versus PCR).

Data observed in the Emilia-Romagna Region, where we performed this study, showed results by cultural method from extremely low prevalences to a total absence of pathogens (0.3\% for VTEC O157:H7; and 0\% for Salmonella spp., Listeria spp., and thermotolerant Campylobacter) (Arrigoni et al., 2009). Despite this apparently low incidence of foodborne pathogens in milk, the risk for consumers is clear: four outbreaks linked to consumption of raw milk were reported in the Emilia-Romagna Region, two due to C. jejuni and two due to E. coli O157:H7 (Arrigoni et al., 2009).

\footnotetext{
${ }^{1}$ Department of Veterinary Medical Sciences, Faculty of Veterinary Medicine, University of Bologna, Ozzano Emilia, Bologna, Italy.

${ }^{2}$ Experimental Institute for Zooprophylaxis in Lombardy and Emilia-Romagna, Brescia, Italy.
} 
The aims of this study were to (i) examine the safety of raw milk sold in a province of the Emilia-Romagna Region in relation to the hygiene quality parameters observed from farm to vending machines; (ii) investigate the presence of Salmonella spp., L. monocytogenes, thermotolerant Campylobacter, and VTEC O157:H7 in raw milk sold in vending machines; (iii) test the performance of three different analytical methods for these foodborne pathogens detection investigating their public health implications; and (iv) investigate if raw milk could be a significant source of exposure of Map for consumers.

\section{Methods}

\section{Raw milk sampling}

All 33 farms authorized to produce and sell raw milk in a province of the Emilia-Romagna Region were considered in the study; the province was taken as an epidemiologic unit because the direct sale of raw milk is allowed only in the province of raw milk production and in neighboring provinces. The province includes about 995,000 people, and the surface of the province is about 370,000 ha; the 33 farms have 60 vending machines selling about 3,500 L/day of raw milk.

The study was conducted from January 2010 to July 2010 in two steps. A total of 211 raw milk samples were collected during the study (66 from farm bulk tanks and 66 from vending machines in the first step; subsequently, in the second step of the study, another 99 from vending machines); all samples were placed in a cool box, stored at $5 \pm 3^{\circ} \mathrm{C}$ until delivery to the laboratory and processed within $6 \mathrm{~h}$ after sampling. For the detection of Map, a portion of raw milk was stored at $-80^{\circ} \mathrm{C}$ until analysis.

In the first step of the study, in order to investigate raw milk hygiene quality parameters from farm bulk tanks to vending machines and to be sure that no fraudulent treatments were performed on raw milk before storage in vending machine, for each of the 33 farms considered, one sample of bulk tank milk and one sample from vending machines were collected on the same day with the goal of sampling the same batch of milk; these samples were analyzed for somatic cell count (SCC), total bacterial count (TBC), inhibitory substances, and alkaline phosphatase. Sampling was repeated twice for a total of 66 samples from bulk tank milk and 66 samples from vending machines.

In the second step of the study, 99 raw milk samples (three for each farm) were collected from vending machines; immediately after arrival in the laboratory, the milk sample was agitated and aseptically partitioned and analyzed for SCC, TBC, inhibitory substances, and alkaline phosphatase, and for the detection of Salmonella spp., L. monocytogenes, thermotolerant Campylobacter, VTEC O157:H7, and Map. Pathogens were selected on the basis of criteria described in regional regulations, with the exception of Map, which was included because its presence in raw milk is currently unknown in Italy.

\section{Laboratory investigations}

Inhibitory substances were determined by Delvotest SP (Tecnomilk ${ }^{\circledR}$ ), and alkaline phosphatase was measured by fluorometric assay using the Fluorophos ${ }^{\circledR}$ ALP Test System. Samples were analyzed using a BactoScan ${ }^{\circledR} 8000$ apparatus to determine TBC, and Fossomatic ${ }^{\circledR} 5000$ was used to determine SCC (Foss A/S, Hillerød, Denmark).
For the detection of Salmonella spp., L. monocytogenes, thermotolerant Campylobacter, and VTEC O157:H7, each raw milk sample was analyzed by three different analytical methods-official cultural method (ISO), modified Bacteriological Analytical Manual (mBAM) cultural method, and polymerase chain reaction (PCR)-whilst for detection of Map only PCR was used.

Official cultural methods. These were performed in accordance with official methods (ISO 11290-1:1996/ Amd.1:2004, ISO 6785/IDF 93:2001, ISO 10272-1:2006, and ISO 16654:2001) on $25 \mathrm{~mL}$ of milk. Oxoid media were used, with the exception of Aloa Agar (Biolife).

mBAM cultural methods. These were performed according to protocols outlined in the U.S. Food and Drug Administration's Bacteriological Analytical Manual (available at http:// www.fda.gov/Food/ScienceResearch/LaboratoryMethods / BacteriologicalAnalyticalManualBAM/default.htm), with two main modifications: (i) $4 \times 210 \mathrm{~mL}$ of milk were centrifuged $(10,000 \times g$ for $10 \mathrm{~min}$ for Salmonella spp., L. monocytogenes, and VTEC O157:H7; and 20,000 $\times g$ for $40 \mathrm{~min}$ for Campylobacter spp.), and the pellets were resuspended and used for cultural examination; and (ii) Aloa Agar was used to replace Palcam agar as isolation media for L. monocyogenes. Oxoid media were used with two exceptions: Aloa Agar (Biolife, Milan, Italy) and RF E. coli O157:H7 agar (R\&F Laboratories, Downers Grove, IL).

PCR analysis. One milliliter of each enriched broth used in mBAM cultural examination was centrifuged to pellet the bacteria in order to extract the bacteria DNA according to directions of the GenElute ${ }^{\mathrm{TM}}$ Bacterial Genomic DNA Mini Kit (SIGMA) for Gram-negative or Gram-positive bacteria. Several PCR protocols were used: for thermotolerant Campylobacter, the DNA preparations were analyzed for the presence or absence of Campylobacter coli and Campylobacter jejuni via qualitative booster-PCR as described by Douglas and Kalischunk (2003). For detection of Salmonella spp., L. monocytogens, and VTEC O157:H7, a real-time PCR was carried out using the Real-Time PCR AB7300 System according to the manufacturer's instructions on the Taqman ${ }^{\circledR}$ Universal PCR Master Mix kit (Applied Biosystems, Foster City, CA). For Salmonella spp. and L. monocytogens, probes and primers designed by Applied Biosystems were used, whilst for VTEC O157:H7 the detection of virulence genes (vtx 1 and $v t x 2$ ) and the serotype identification (O157:H7) were performed with probe and primers described by Perelle et al. (2004); the virulence gene eae was detected with primers described by Nielsen and Andersen (2003).

Identification of isolates. For Salmonella spp., the isolated strain was analyzed by the riboprinting method described by De Cesare et al. (2001); for C. jejuni and C. coli, the bacterial DNA was extracted and purified using the NucleoSpin Tissue kit (Mecherey-Nagel, Düren, Germnay) as described by the manufacturer, and a multiplex PCR protocol described by Denis et al. (1999) was used. For VTEC O157:H7, the serotype and the presence of stx1, st $x 2$, and eae genes in E. coli O157: H7 isolate were confirmed by PCR as described above.

Map examination. DNA was extracted directly from milk by the Adiapure Milk extraction kit, and PCR was performed 
Table 1. Results of Detection and Isolation of the Pathogens by Different Analytical Methods Used

\begin{tabular}{lcccc}
\hline & $\begin{array}{c}\text { Salmonella } \\
\text { spp. }\end{array}$ & $\begin{array}{c}\text { Listeria } \\
\text { monocytogenes }\end{array}$ & $\begin{array}{c}\text { Thermotolerant } \\
\text { Campylobacter }\end{array}$ & $\begin{array}{c}\text { VTEC } \\
\text { O157:H7 }\end{array}$ \\
\hline Total samples analyzed & 99 & 99 & 99 & 99 \\
Samples positive by real-time PCR & 0 & 1 & 1 & 99 \\
Samples positive by cultural ISO & 0 & 0 & 0 & 3 \\
Samples positive by cultural BAM & 1 & 0 & 1 & 0 \\
Percentage positive samples & $1.01 \%$ & $1.01 \%$ & $2.02 \%$ & 1 \\
NP $\%$ & $1.01 \%$ \\
\hline
\end{tabular}

PCR, polymerase chain reaction; ISO, official cultural method; BAM, Bacteriological Analytical Manual; NP, not performed.

by targeting IS900 (Ricchi et al., 2009) on the Real Time PCR StepOne Plus System (Applied Biosystems) in a final volume of $20 \mu \mathrm{L}$. Positive and doubtful samples were confirmed by nested PCR as previously reported (Ricchi et al., 2009) using GoTaq $^{\circledR}$ Flexi DNA Polymerase (Promega, Milan, Italy).

\section{Statistical analysis}

Statistical analysis for mean of SCC and TBC was performed using original values, and the independent $t$-test was used to compare the means between two unrelated groups on the same continuous and dependent variable of raw milk samples collected at farms and vending machines. The Exact Fischer's test was used to evaluate (i) the performance of the analytical methods used comparing the number of positive samples obtained by the three methods; (ii) the influence of volume of milk tested ( 25 versus $210 \mathrm{~mL}$ ) on detection rate of all pathogens because all three methods provide a selective enrichment phase and considering the theoretical sensitivity of the three methods in one viable cell in the volume of milk tested. Data were analyzed using SPSS for Windows (version 12.0), and the level of statistical significance was set at 0.05 .

\section{Results}

All 211 raw milk samples collected from vending machines in the first and in the second part of the study met the requirements for alkaline phosphatase $(>350,000 \mathrm{mU} / \mathrm{mL})$, and no inhibitory substances were detected.

The correlation between milk samples collected on the same day from bulk tanks $(n=66)$ and vending machines $(n=66)$, in the first part of the study, showed that a total of $7.5 \%$ samples from bulk tank and $12.1 \%$ from vending machines had SCC > $300,000 / \mathrm{mL}$ with an average value, respectively, of 234,589 and $234,965 \mathrm{cell} / \mathrm{mL}$ and that a total of $19.35 \%$ samples from bulk tank and $36.4 \%$ from vending machines had TBC> $50,000 \mathrm{CFU} / \mathrm{mL}$, with an average of 45,580 and 93,389 CFU/ $\mathrm{mL}$, respectively. The $t$-test showed a significant difference between the mean TBC of milk samples from bulk tanks and milk samples from vending machines ( $p=0.001)$; no significant differences were found for SCC $(p=0.54)$.

Considering TBC and SCC of all 165 samples resulted from collection from vending machines of both steps of the study, we observed that raw milk quality was not adequate for this type of production and frequently in disagreement with limits fixed by law: $18.8 \%$ of samples had SCC $>300,000 / \mathrm{mL}$ (with a mean of $234,874 / \mathrm{mL}$ ), and $44.8 \%$ had TBC $>50,000 \mathrm{CFU} / \mathrm{mL}$ (with an average value of $110,551 \mathrm{CFU} / \mathrm{mL}$ ), which is more than double the official limit.
Results on isolation and detection of Salmonella spp., L. monocytogenes, thermotolerant Campylobacter, and VTEC O157: H7 with different methods are summarized in Table 1. No more than one pathogen was isolated from each sample. The isolated pathogenic bacteria were identified as VTEC O157:H7 (stx1, stx2, and eae positive), Salmonella Thyphimurium, and Campylobacter jejuni. None of the three methods performs significantly better than the others; however, a higher volume of milk tested, basically $210 \mathrm{~mL}$ by $\mathrm{mBAM}$ and PCR, and $25 \mathrm{~mL}$ by ISO, has merit in increasing significantly the detection rate (Chi square $=5.1 ; p=0.03$ ).

Three samples (3\%) from three different farms (10\%) were positive for Map.

\section{Discussion}

The fact that all raw milk samples met the requirements for alkaline phosphatase and that there were no differences in SCC values between bulk tanks and vending machine samples indicate that the milk was not subject to heat treatment and that no centrifugation or filtration was applied by farmers before placing the milk in the vending machines. These results, together with the absence of inhibitory substances, exclude the most common fraudulent treatments potentially applied to reduce the SCC or the bacterial contamination of milk.

The high average value of TBC observed (110,551 CFU/ $\mathrm{mL}$ ) poses a not negligible threat for human safety because the production of raw milk with such bacteria count level does not guarantee hygienic quality standards for consumers. The significant increase of TBC from bulk tank milk samples to vending machine milk samples highlights a mishandling of milk, which may result in an increase of pathogenic microbial load, raising further questions on raw milk safety.

All the pathogens investigated were detected in raw milk sold at vending machines, although the prevalence rates can be considered low. Prevalences resulted in agreement with data in literature for VTEC O157:H7 but lower for Salmonella spp., L. monocytogenes, and thermotolerant Campylobacter (Desmasures et al., 1997; Dontorou et al., 2003; Meyer-Broseta et al., 2003; Oliver et al., 2005, 2009). Even for paratubercolosis, the amount of herds and samples positive for Map are lower than those reported by other European countries (Corti et al., 2002; Grant et al., 2002; Jayarao et al., 2004; O’Reilly et al., 2004; Ayele et al., 2005; Slana et al., 2008; Nielsen and Toft, 2009), but the positivity of $3 \%$ of samples highlights that raw milk consumption can be a significant source of exposure of consumer to Map. In spite of variations, all the surveys demonstrated that milk could be a major source of foodborne pathogens of human health significance, even though detection may be 
sporadic for very low to low levels of bacterial contamination (Oliver et al., 2005).

None of the positive samples were detected with the official ISO methods defined in the Regional regulation ISO and mBAM cultural methods use media very similar in composition, and the higher isolation rate of the mBAM cultural method associated with PCR may be explained by the higher volume of milk tested. Consequently, the use of analytical methods that increase the sensitivity is suggested. On this basis, the absence of pathogens in $25 \mathrm{~mL}$ and a presence in $210 \mathrm{~mL}$ leads us to suppose that the contamination level, in positive samples, should be on the order of "units" of pathogenic bacteria per liter. Consequently, the ISO method, performed on $25 \mathrm{~mL}$ of milk, seems to be inefficient in detecting the contamination of pathogens in milk, given that extremely small numbers of organisms are present and that they may not be evenly distributed in the milk. Nevertheless, it should be considered that extremely small amounts of bacteria may be infectious and that pathogens may proliferate after testing to levels that reach unacceptable risks (LeJeune and Rajala-Schultz, 2009).

\section{Conclusion}

Raw milk sold in vending machines in the considered province does not have an optimal microbiological quality and does not meet criteria fixed by law in terms of safety for hygienic quality and for exposition to all the pathogenic bacteria investigated in the study. The viability of isolates of Salmonella Thyphimurium, Campylobacter jejuni, and VTEC O157:H7 in commercially sold raw milk and the presence of Map pose a clear risk for consumers and could have serious public health consequences. The mishandling of raw milk from farm to vending machine was demonstrated and may increase the risk due to the presence of foodborne pathogens in raw milk. The finding of positive samples by the ISO method, as fixed by Regional regulation, seems to be inefficient as the only way to recall an unsafe product from the market. A different approach for the management and control of raw milk chain is required through the following three steps: (i) implementation of on-farm pre-requisites for the authorization to produce and sell raw milk; (ii) implementation of Good Dairy Farming Practices; (iii) improvement of handling procedures and control of low temperature in farm, during transport, and in vending machine, which is essential and must be enforced by official systems in order to reduce pathogenic microbial growth potentially present in raw milk. In addition, a realistic analysis of raw milk consumer habits is required.

\section{Disclosure Statement}

No competing financial interests exist.

\section{References}

Arrigoni N, Scavia G, Tamba M. Latte crudo: Esperienze e problematiche igienico-sanitarie in Regione Emilia-Romagna. Large Anim Rev 2009;15:215-219.

Ayele WY, Svastova P, Roubal P, et al. Mycobacterium avium subspecies paratuberculosis cultured from locally and commercially pasteurized cow's milk in the Czech Republic. Appl Environ Microbiol 2005;71:1210-1214.
Corti S, Stephan R. Detection of Mycobacterium avium subspecies paratuberculosis specific IS900 insertion sequences in bulk-tank milk samples obtained from different regions throughout Switzerland. BMC Microbiol 2002;2:15.

De Cesare A, Manfreda G, Dambaugh TR, et al. Automated ribotyping and random amplified polymorphic DNA analysis for molecular typing of Salmonella enteritidis and Salmonella typhimurium strains isolated in Italy. J Appl Microbiol 2001; 91:780-785.

Denis M, Soumet C, Rivoal K, et al. Development of a m-PCR assay for simultaneous identification of Campylobacter jejuni and Campylobacter coli. Lett Appl Microbiol 1999;29:406-410.

Desmasures N, Bazin F, Guéguen M. Microbiological composition of raw milk from selected farms in the Camembert region of Normandy. J Appl Microbiol 1997;83:53-58.

Dontorou C, Papadopoulou C, Filioussis G, et al. Isolation of Escherichia coli O157:H7 from foods in Greece. Int J Food Microbiol 2003;82:273-279.

Douglas GI, Kalischuk LD. Use of PCR for direct detection of Campylobacter species in bovine feces. Appl Environ Microbiol 2003;69:3435-3447.

Grant IR, Ball HJ, Rowe MT. Incidence of Mycobacterium paratuberculosis in bulk raw and commercially pasteurized cow's milk from approved dairy processing establishments in the United Kingdom. Appl Environ Microbiol 2002;68:2428-2435.

[ISO] International Organization for Standardization. ISO 11290-1:1996. Microbiology of food and animal feeding stuffs-Horizontal method for the detection and enumeration of Listeria monocytogenes-Part 1: Detection method.

[ISO] International Organization for Standardization. ISO 16654:2001. Microbiology of food and animal feeding stuffsHorizontal method for the detection of Escherichia coli O157.

[ISO] International Organization for Standardization. ISO 6785:2001 (IDF 93:2001). Milk and milk products-Detection of Salmonella spp.

[ISO] International Organization for Standardization. ISO 11290-1:1996/Amd 1:2004. Modification of the isolation media and the haemolysis test, and inclusion of precision data.

[ISO] International Organization for Standardization. ISO 10272-1:2006. Microbiology of food and animal feeding stuffs-Horizontal method for detection and enumeration of Campylobacter spp.-Part 1: Detection method.

Jayarao BM, Pillai SR, Wolfgang DR, et al. Evaluation of IS900PCR assay detection of Mycobacterium avium subspecies paratuberculosis infection in cattle using quarter milk and bulk tank milk samples. Foodborne Pathog Dis 2004;1:17-26.

LeJeune JT, Rajala-Schultz PJ. Unpasteurized milk: A continued public health threat. Clin Infect Dis 2009;48:93-100.

Meyer-Broseta S, Diot A, Bastian S, et al. Estimation of low bacterial concentration: Listeria monocytogenes in raw milk. Int J Food Microbiol 2003;80:1-15.

Nielsen E, Andersen M. Detection and characterization of Verocytotoxin producing Escherichia coli by automated 5' nuclease PCR assay. J Clinical Microbiol 2003;41:2884-2893.

Nielsen SS, Toft N. A review of prevalences of paratuberculosis in farmed animals in Europe. Prev Vet Med 2009;88:1-14.

Oliver SP, Jayarao BM, Almeida RA. Foodborne pathogens in milk and dairy farm environment: Food safety and public health implications. Foodborne Pathog Dis 2005;2:115-129.

Oliver SP, Boor KJ, Murphy SC, et al. Food safety hazards associated with consumption of raw milk. Foodborne Pathog Dis 2009;6:793-806.

O'Reilly CE, O'Connor L, Anderson W, et al. Surveillance of bulk raw and commercially pasteurized cows' milk from approved 
Irish liquid-milk pasteurization plants to determine the incidence of Mycobacterium paratuberculosis. Appl Environ Microbiol 2004;70:5138-5144.

Perelle S, Dilasser F, Grout J, et al. Detection by 5'- nuclease PCR of Shiga-toxin producing Escherichia coli O26, O55, O91, O103, O111, O113, O145 and O157:H7, associated with the world's most frequent clinical cases. Mol Cell Probes 2004;18:185-192.

Ricchi M, Manini F, Cammi G, et al. Comparison of four different PCR methods for the detection of Mycobacterium avium subsp. paratuberculosis in milk. Proc 10th Int Colloq Paratuberculosis $56-59$.

Slana I, Kralik P, Kralova A, et al. On-farm spread of Mycobacterium avium subsp. paratuberculosis in raw milk studied by
IS900 and F57 competitive real time quantitative PCR and culture examination. Int J Food Microbiol 2008;128:250-257.

Address correspondence to: Federica Giacometti, Ph.D. Department of Veterinary Medical Sciences

Faculty of Veterinary Medicine University of Bologna

Via Tolara di Sopra 50

40064 Ozzano Emilia, Bologna, Italy

E-mail: federica.giacometti3@unibo.it 